\title{
Failure of cimetidine to suppress immunoreactive parathyroid hormone and hypercalcaemia in primary hyperparathyroidism
}

\author{
RichaRd B. MALletT \\ L.R.C.P., M.R.C.S.
}

\author{
RICHARD SAINSBURY \\ M.B., Ch.B.(N.Z.)
}

\author{
KenNeth G. F. Benton \\ M.R.C.P.
}

Department of Geriatric Medicine, St Helen's Hospital, Hastings, Sussex

\begin{abstract}
Summary
Cimetidine has been reported as suppressing the excess parathyroid hormone secretion and hypercalcaemia seen in hyperparathyroidism. A case of primary hyperparathyroidism is described, in which the level of circulating parathyroid hormone and hypercalcaemia remain entirely unaffected by cimetidine. The drug is implicated in the management of primary hyperparathyroidism unsuitable for surgery, but present evidence, as reviewed, is insufficient to recommend the use of cimetidine in this way.
\end{abstract}

\section{Introduction}

The available precision of serum calcium estimations, and the sensitivity of radioimmune assay techniques, have identified primary hyperparathyroidism as a common disorder. The prevalence of this condition increases with age and the incidence is greater in women. The mechanism of primary hyperparathyroidism is not yet clear, unlike the hallmarks of the disease: hypercalcaemia and increased production of parathyroid hormone (PTH). A series of patients with primary hyperparathyroidism has been reported in which hypersecretion of parathyroid hormone, and to a lesser extent hypercalcaemia, was suppressed by cimetidine in all cases. This present report refers to the view that such suppression may confer no benefit in the hyperparathyroid state, does not always occur and so is unpredictable, and that a place for cimetidine in the diagnosis and management of primary hyperparathyroidism is not proved.

\section{Case report}

An 81-year-old white female presented with a cerebrovascular accident. Two years earlier the arterial blood pressure had been recorded as $230 / 130 \mathrm{mmHg}$ consistently reproduced, and lowered by diuretics. A barium meal at that time was reported to show a duodenal ulcer. Intermittent occult bleeding and iron deficiency anaemia were subsequently noted. Non-specific symptoms, in $\frac{N}{N}$ cluding lassitude, vague depression and anxiety ${ }_{0}$ were long-standing and prominent until the time of admission. Examination found her to be obtunded with a complete right hemiplegia and expressive dysphasia. Atrial fibrillation and cardiac enlargement were present. Corneal calcification a\&d clinical abnormalities of the neck were not detected.The arterial blood pressure was $220 / 140 \mathrm{mmHg}$ \& $\mathrm{en}$. admission and settled in the normal range of own accord. Oral cimetidine $400 \mathrm{mg} 4$ times daily was given alone over 4 weeks from the eighth day, and calcium homoeostasis observed.

Investigation. Blood samples were taken only in the uncuffed, recumbent fasting state. Results of 3 serum calcium, phosphate, circulating PTH levelsare given in Table 1 after correction of serumo calcium for the concentration of serum albumin.

Serum creatinine $112 \mu \mathrm{mol} / \mathrm{l}$, creatinine clearance $44 \mathrm{ml} / \mathrm{min}$. Urine calcium $6.8 \mathrm{mmol} / 24 \mathrm{hr}$. Serumo thyroxine $93 \mathrm{nmol} / \mathrm{l}$ (normal 55-156 nmol/1) Electrocardiogram: left ventricular hypertrophyo and atrial fibrillation. Chest radiograph: left ventricular enlargement, lung fields and rib cageo normal. Plain skull and abdominal radiographs normal. Hand radiographs: sub-periosteal erosionso of phalanges and terminal digital tufts.

\section{Discussion}

Primary hyperparathyroidism has been described స్టు as a reversible cause of cimetidine-resistant gastrico acid hypersecretion (McCarthy et al., 1979). Ito occurred during the management of a gastrinoma with long-term oral cimetidine therapy. This alludes? to an inability of the drug to prevent and suppress the development of hyperparathyroidism or itso systemic effects. A study has since been reported on 
TABLE 1. Results of serum calcium and phosphate and circulating PTH after correction of serum calcium for the concentration of serum albumin

\begin{tabular}{lcccccccccc}
\hline & \multicolumn{1}{c}{ Cimetidine } \\
\cline { 2 - 9 } \multicolumn{1}{c}{ Days after admission } & 4 & 8 & 12 & 16 & 20 & 24 & 28 & 32 & 36 & 40 \\
\hline Serum calcium (mmol/l) & 2.88 & 2.64 & 2.78 & 2.69 & 2.78 & 2.91 & 3.09 & 2.84 & 2.87 & 2.79 \\
Serum phosphate (mmol/l) & 0.81 & 0.72 & 0.67 & 0.70 & 0.77 & 0.82 & 0.92 & 0.83 & 0.81 & 0.71 \\
PTH (pg/ml) & 172 & & & 165 & & 183 & & 179. \\
\hline
\end{tabular}

PTH: amino terminal PTH assay (normal less than $130 \mathrm{pg}, 1-34 \mathrm{HPTH} / \mathrm{ml}$ ).

the influence of cimetidine on circulating parathyroid hormone in primary hyperparathyroidism (Sherwood, Ackroyd and Garcia, 1980). In all 12 patients in the study the increased PTH levels fell dramatically into the normal range for circulating PTH inside 4 weeks of cimetidine treatment. At the time of diagnosis only 8 of the patients were hypercalcaemic and, despite an early reduction in the serum calcium on cimetidine, none of these patients achieved normocalcaemia. Symptoms were present, even in the normocalcaemic group, and varied in close relation to the PTH levels. These findings prompted the considerations that cimetidine may block the synthesis or release of parathyroid hormone from adenomas, and that PTH and not hypercalcaemia is the mediator of symptoms in primary hyperparathyroidism. In the report of this study, distinction of the normocalcaemic group from a secondary hyperparathyroid state, maintaining a normal serum calcium is not permitted (MacGregor, 1980). Hypocalcaemia after parathyroid tumour removal was not seen in this study in those patients prepared for operation with cimetidine. This suggests that cimetidine distinguishes between normal and adenomatous parathyroid tissue, allowing recovery of the normal tissue while suppressing the other. The inference is that were the normocalcaemic group in a secondary hyperparathyroid state the PTH levels in these patients would not have been lowered by cimetidine. These are unproved suppositions and carry the implication that, because PTH and not hypercalcaemia is suggested as the producer of symptoms, the systemic effects and symptoms of primary and secondary hyperparathyroid states would be identical. This does not account for symptoms identical to those seen in primary hyperparathyroid resulting from hypercalcaemia per se, when the PTH levels would be expected to be low. This present case report lacks histological proof, but has clinical support and biochemical confirmation of primary hyperparathyroidism. Both the circulating PTH levels and corrected serum calcium levels were entirely unaffected by oral cimetidine. Whether absorption of the drug took place, or that in some patients cimetidine or its metabolites interfered with the radioimmune assays for circulating PTH is not known. Some other studies have suggested a possible relationship between cimetidine and hyperparathyroid disease of an uncertain nature. There is no objective evidence of any beneficial effect on the hyperparathyroid state (Heath, 1980), and at present cimetidine must exert no influence on the present accepted state of diagnosis and management of primary hyperparathyroidism.

\section{Acknowledgment}

We are indebted to Dr R. E. Irvine for his encouragement and kind permission to report the case.

\section{References}

McCarthy, D.M., Peikin, S.R., Lopatin, R.N., Long, B.W., Speigal, A., MARX, S. \& BrenNan, M. (1979) Hyperparathyroidism-a reversible cause of cimetidine-resistant gastric hypersecretion. British Medical Journal, i, 1765.

SHERWOOD, J.K., ACKROYD, F.W. \& GARCIA, M. (1980) Effect of cimetidine on circulating parathyroid hormone in primary hyperparathyroidism. Lancet, i, 616.

MACGREGoR, G.A, (1980) Cimetidine in hyperparathyroidism. Lancet, $\mathbf{i}, 980$.

Heath, H. III. (1980) Cimetidine in hyperparathyroidism. Lancet, $\mathbf{i}, 980$. 